\title{
Hepatitis B virus genotypes circulating in Brazil: molecular characterization of genotype $F$ isolates
} Francisco CA Mello*1, Francisco JD Souto ${ }^{2}$, Leticia C Nabuco ${ }^{3}$, Cristiane A Villela-Nogueira ${ }^{3}$, Henrique Sergio $\mathrm{M} \mathrm{Coelho}^{3}$, Helena Cristina F Franz ${ }^{4}$, Joao Carlos P Saraiva ${ }^{5}$, Helaine A Virgolino ${ }^{6}$, Ana Rita C MottaCastro7$^{7}$, Mabel MM Melo ${ }^{8}$, Regina MB Martins ${ }^{9}$ and Selma A Gomes ${ }^{1}$

Address: ${ }^{1}$ Laboratório de Virologia Molecular, Instituto Oswaldo Cruz, FIOCRUZ, Rio de Janeiro, Brazil, ${ }^{2}$ Faculdade de Ciências Médicas, Universidade Federal de Mato Grosso, Cuiabá, Brazil, ${ }^{3}$ Hospital Universitário Clementino Fraga Filho, Universidade Federal do Rio de Janeiro, Rio de Janeiro, Brazil, ${ }^{4}$ Universidade Federal de Santa Catarina, Florianópolis, Brazil, ${ }^{5}$ Centro de Hemoterapia e Hematologia do Pará, Belém, Brazil, ${ }^{6}$ Laboratório Central de Saúde Pública do Amazonas, Manaus, Brazil, ${ }^{7}$ Centro de Ciências Biológicas e da Saúde, Universidade Federal de Mato Grosso do Sul, Campo Grande, Brazil, ${ }^{8}$ Laboratório Central de Saúde Pública de PernambucoDr. Milton Bezerra Sobral, Recife, Brazil and 'Instituto de Patologia Tropical e Saúde Pública, Departamento de Microbiologia, Universidade Federal de Goiás, Goiânia, Brazil

Email: Francisco CA Mello* - fcamello@ioc.fiocruz.br; Francisco JD Souto - fsouto@terra.com.br; Leticia C Nabuco - leticia.nabuco@terra.com.br; Cristiane A Villela-Nogueira - crisvillela@terra.com.br; Henrique Sergio M Coelho - henriquesmc@hucff.ufrj.br; Helena Cristina F Franz - franz@ccs.ufsc.br; Joao Carlos P Saraiva - saraiva@amazon.com.br; Helaine A Virgolino - helainevirgolino@yahoo.com.br; Ana Rita C Motta-Castro - an.castro@terra.com.br;

Mabel MM Melo - mabelm4@yahoo.com.br; Regina MB Martins - rbringel@terra.com.br; Selma A Gomes - selma@ioc.fiocruz.br

* Corresponding author

Published: 23 November 2007

BMC Microbiology 2007, 7:103 doi:10.1186/147|-2180-7-103
Received: 26 July 2007

Accepted: 23 November 2007

This article is available from: http://www.biomedcentral.com//47/-2/80/7//03

(c) 2007 Mello et al; licensee BioMed Central Ltd.

This is an Open Access article distributed under the terms of the Creative Commons Attribution License (http://creativecommons.org/licenses/by/2.0), which permits unrestricted use, distribution, and reproduction in any medium, provided the original work is properly cited.

\begin{abstract}
Background: Hepatitis $B$ virus (HBV) isolates have been classified in eight genotypes, $A$ to $H$, which exhibit distinct geographical distributions. Genotypes A, D and F are predominant in Brazil, a country formed by a miscegenated population, where the proportion of individuals from Caucasian, Amerindian and African origins varies by region. Genotype F, which is the most divergent, is considered indigenous to the Americas. A systematic molecular characterization of $\mathrm{HBV}$ isolates from different parts of the world would be invaluable in establishing HBV evolutionary origins and dispersion patterns. A large-scale study is needed to map the region-by-region distribution of the HBV genotypes in Brazil.

Results: Genotyping by PCR-RFLP of 303 HBV isolates from HBsAg-positive blood donors showed that at least two of the three genotypes, $A, D$, and F, co-circulate in each of the five geographic regions of Brazil. No other genotypes were identified. Overall, genotype $A$ was most prevalent (48.5\%), and most of these isolates were classified as subgenotype AI (I38/I53; 90.2\%). Genotype D was the most common genotype in the South $(84.2 \%)$ and Central $(47.6 \%)$ regions. The prevalence of genotype $\mathrm{F}$ was low (I3\%) countrywide. Nucleotide sequencing of the $\mathrm{S}$ gene and a phylogenetic analysis of $32 \mathrm{HBV}$ genotype $\mathrm{F}$ isolates showed that a great majority $(28 / 32$; $87.5 \%$ ) belonged to subgenotype $\mathrm{F} 2$, cluster II. The deduced serotype of $3 \mathrm{I}$ of $32 \mathrm{~F}$ isolates was adw4. The remaining isolate showed a leucine-to-isoleucine substitution at position 127 .
\end{abstract}

Conclusion: The presence of genotypes A, D and F, and the absence of other genotypes in a large cohort of HBV infected individuals may reflect the ethnic origins of the Brazilian population. The 
high prevalence of isolates from subgenotype AI (of African origin) indicates that the African influx during the colonial slavery period had a major impact on the circulation of HBV genotype $A$ currently found in Brazil. Although most genotype $F$ isolates belonged to cluster II, the presence of some isolates belonging to clusters I (subgroup Ib) and IV suggests the existence of two or more founder viral populations of genotype $F$ in Brazil.

\section{Background}

Hepatitis B virus (HBV) is the prototype of the Hepadnaviridae family characterized by DNA viruses with tropism to hepatic cells. HBV is an etiologic agent of human liver diseases, including acute and chronic hepatitis, cirrhosis, and hepatocellular carcinoma. As such, it constitutes a significant public health problem, estimated to chronically infect more than 350 million people worldwide (reviewed in [1]).

The HBV genome is a partially double-stranded circular DNA molecule approximately $3.2 \mathrm{~kb}$ in length. The viral proteins are encoded by four partially overlapping open reading frames (ORFs), which allow the virus to produce $50 \%$ more proteins than would be predicted by the small genome size. HBVs also have an unusual replication strategy. Because they first synthesize RNA intermediates from which DNA is synthesized by reverse transcription, the HBV DNA viruses have substitution rates more than 10fold higher than other DNA viruses.

On the basis of genetic differences, HBV have been classified into eight genomic groups (A-H). Entire genome sequences within each group diverge from other groups by more than $8 \%$. These eight groups have distinct geographical distributions [2,3]. Genotype A is distributed globally and is the main genotype found in Europe, North America, Africa and India. Genotypes B and C are predominant in East and Southeast Asia, and Australia. Genotype $\mathrm{D}$ is mainly found in the Middle East and Mediterranean countries but has been reported globally, whereas genotype $\mathrm{E}$ seems to be predominant in West Africa. Genotype $\mathrm{G}$ has been characterized in samples from USA, Mexico and France, and genotypes $\mathrm{F}$ and $\mathrm{H}$ are found exclusively in Central and South America (reviewed in $[4,5])$.

Some genotypes have been further subdivided into subgroups (subgenotypes) with distinct geographic origins. The HBV genotype A strain is now divided into three genetic clusters. Subgenotype A1 represents isolates with an African-Asian origin, whereas subgenotype A2 includes isolates with European-North American origin [6]. Recently, a new subgenotype, designated A3, was described in Cameroon [7]. Genotypes B [3,8-10], and C $[3,11,12]$ have each been subdivided into four subgenotypes, and genotype $\mathrm{D}[3,13,14]$ has been subdivided into five subgenotypes. Genotype F, which constitutes the most divergent group [15], is indigenous to the Americas and is the major circulating genotype in Argentina [1618], Venezuela $[19,20]$, the Peruvian Amazon Basin [21], Northern Brazil [22] and Central American countries, including Costa Rica, El Salvador and Nicaragua [23]. Recently, two subgenotypes, F1 and F2, have been proposed for this genotype, each characterized by a specific amino acid residue, Leu ${ }^{45}$ and $\mathrm{Thr}^{45}$, respectively, in the small (S) gene product [24]. A subdivision of isolates from genotype F into five clusters (Ia, Ib, II, III and IV) has also been proposed by Mbayed et al. on the basis of comparisons between S gene sequences [25]. Clusters Ia and $\mathrm{Ib}$, associated with subgenotype $\mathrm{F} 1$, are representative of strains found mainly in Central America and Argentina, respectively. Subgenotype F2 includes clusters II (Nicaragua, Venezuela, and Brazil), III (Panama, Venezuela, and Colombia) and IV (Argentina and Bolivia) (reviewed in [4]).

Brazil is a federation of 26 states and one federal district occupying approximately $8,500,000 \mathrm{~km}^{2}$ divided broadly into five geographic regions: North, Northeast, CentralWest, Southeast and South. Early studies have shown variability in HBV prevalence in different Brazilian regions. The Amazon basin, corresponding to the North region and the northern portions of the Central-West region, is characterized by a rate of endemic HBV infection, in contrast to the low prevalence found in southern regions of the country [22,26-28]. Brazil, a country with a highly miscegenated population, exhibits an HBV genotype circulation pattern that is distinct from the distribution found in other Latin American countries, with genotypes $\mathrm{A}, \mathrm{D}$ and $\mathrm{F}$ being the most prevalent among HBV carriers [29-31].

In this study, we performed a molecular characterization of HBV strains derived from HBsAg-positive blood donors living in different Brazilian regions. S region nucleotide sequencing and phylogenetic analysis were performed to determine the relationships between HBV genotype F isolates from Brazil and from other American countries.

\section{Results}

\section{Distribution of HBV genotypes in Brazil}

Genotyping by PCR-RFLP of 303 HBV isolates from all five Brazilian geographic regions demonstrated that geno- 
types A, D and F were present at different frequencies; no other genotypes were identified in the samples analyzed. Genotype A was the most prevalent in the North (52/82; $63.4 \%)$, Northeast $(13 / 24 ; 54.2 \%)$ and Southeast $(36 / 56$; $64.3 \%$ ) regions. Genotype D was the most prevalent in South $(32 / 38 ; 84.2 \%)$, whereas genotype F isolates were absent in this region (Figure 1). In the center of the country, represented by the Central-West region, there was a balanced distribution of genotypes A (46/103; 44.7\%) and D $(49 / 103 ; 47.6 \%)$. Countrywide, genotype A was the most common $(48.5 \%)$, followed by genotype D (38.5\%) and genotype $\mathrm{F}(13 \%)$.

As shown in a previous work [31], the PCR-RFLP genotyping method divided each genotype in different RFLP patterns. In the current study, a total of thirteen RFLP patterns were observed (Table 1). Genotype A isolates were subdivided into four patterns, AI-AIV, the great majority of which were classified as AI or AII (138/153; 90.2\%). Among the five RFLP patterns found for genotype D (DIDV), patterns DI and DII were the most prevalent (92/ $116 ; 79.3 \%)$. For genotype F, FI was the most frequent pattern $(20 / 34 ; 58.8 \%)$ of the four patterns found (FI-FIII, FV).

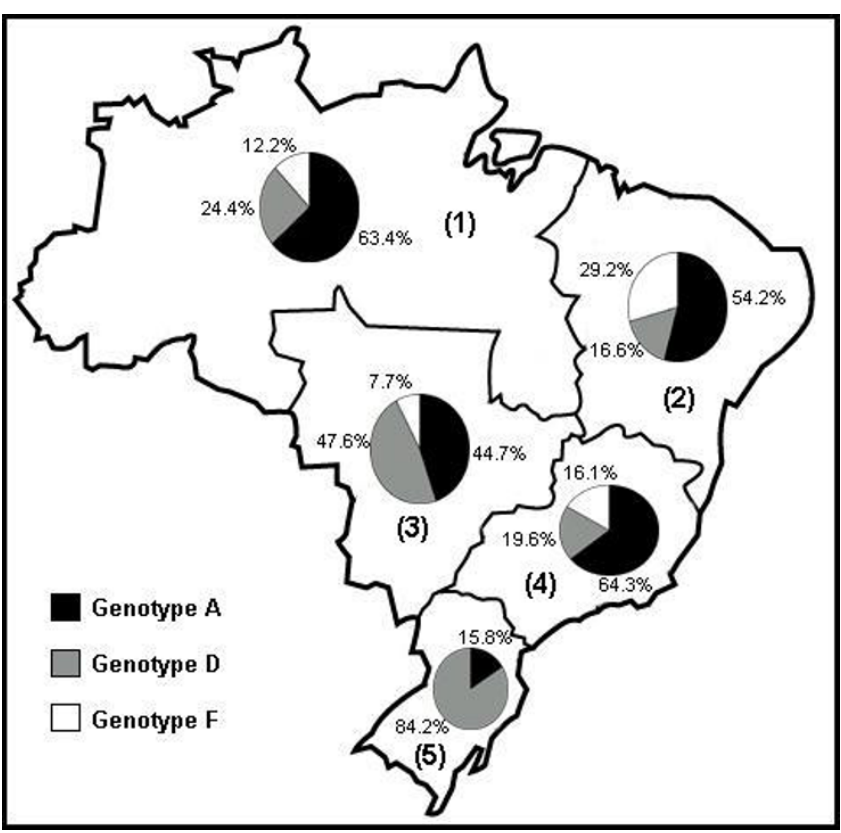

Figure I

Distribution of HBV genotypes in different Brazilian regions. Map representing HBV genotypic distribution in all five Brazilian regions ( 1 - North region; 2 - Northeast region; 3 - Central-West region; 4 - Southeast region; 5 South region).

\section{Phylogenetic analysis of the small (S) gene and amino acid replacements}

The results of PCR-FRLP analysis were confirmed by direct nucleotide sequencing of HBV S gene PCR products from 62 of 303 samples (20.5\%), including randomly selected samples from genotype A (22 samples) and genotype D (13 samples), and 27 samples from genotype F. No discrepancies were found between the two methods. Among genotype A samples, 15/22 (68.2\%) were classified as subgenotype A1 and 7/22 (31.8\%) as subgenotype A2. A phylogenetic analysis of genotype D samples assigned 10/ $13(76.9 \%)$ to subgenotype D3 and 3/13 (23.1\%) to subgenotype D2. The deduced amino acid sequence of the S gene product and an analysis of antigenic determinant $a$ residues 122 and 127 confirmed the expected serotype pattern of all but one genotyped sample. All $22 \mathrm{HBV}$ genotype A samples were classified as serotype adw2. Nine genotype D samples were classified as serotypes ayw2 and three were identified as ayw3. Of the $32 \mathrm{HBV}$ genotype $\mathrm{F}$ samples, 31 were $a d w 4$, and one, 052-N, had an unusual substitution of isoleucine for leucine at residue 127 . Three HBV genotype A isolates (358-S; 312-SE; 161-CW) were shown to harbor tyrosine to cysteine substitutions in determinant a residue 100 (Y100C), and the T118VA128V double mutant was found in three genotype D isolates (Table 2). The partial amino acid sequence of HBV polymerase showed amino acid substitutions related to the lamivudine-resistance phenotype in two isolates derived from this group of HBsAg positive blood donors. One (209-CW) displayed the double rtL180M-rtM204V lamivudine-resistance mutation and the other $(043-\mathrm{N})$ showed an additional rtV173L mutation, which is also associated with lamivudine resistance [32] (Table 2).

\section{Molecular characterization of genotype $\boldsymbol{F}$ isolates}

A phylogenetic analysis of the $S$ gene sequences from 32 HBV genotype $\mathrm{F}$ isolates (27 from blood donors and 5 previously characterized serum samples from the native Amerindian Apurinã tribe) in a set with 27 international HBV genotype F sequences (GenBank), classified genotype $\mathrm{F}$ isolates into five different subgroups (Figure 2). Using the topology of the phylogenetic tree, we were able to identify the subgenotypes F1 and F2 (Figure 2). The vast majority of Brazilian genotype F strains determined in the present study $(28 / 32 ; 93.75 \%)$ were classified as subgenotype F2, whereas only two samples $(2 / 32 ; 6.25 \%)$ were grouped into subgenotype F1. An amino acid analysis supported this finding, showing that all samples grouped into the F2 subgenotype by the phylogenetic analysis contained a threonine at position 45 of the $\mathrm{S}$ gene product, whereas the two subgenotype F1 samples had a leucine at this position (data not shown). The tree topology also allowed us to identify the five genotype F clusters (Figure 2 ). Twenty-eight of 32 samples analyzed (87.5\%) were classified into cluster II and 2 samples (6.25\%) were 
Table I: Distribution of RFLP patterns in HBV isolates of HBsAg-positive blood donors living in different Brazilian geographic regions.

\begin{tabular}{|c|c|c|c|c|c|c|c|c|c|c|c|c|c|c|}
\hline \multirow{3}{*}{ Brazilian regions } & \multicolumn{13}{|c|}{ RFLP patterns } & \multirow{3}{*}{ TOTAL } \\
\hline & \multicolumn{4}{|c|}{ Genotype A } & \multicolumn{5}{|c|}{ Genotype D } & \multicolumn{4}{|c|}{ Genotype F } & \\
\hline & Al & All & AlII & AIV & DI & DII & DIII & DIV & DV & $\mathbf{F I}$ & FII & FIII & FV & \\
\hline South & 3 & 1 & 2 & - & 15 & 13 & - & 3 & I & - & - & - & - & 38 \\
\hline Southeast & 21 & 8 & 6 & 1 & 4 & 7 & - & - & - & 3 & 3 & 2 & I & 56 \\
\hline Central-West & 34 & 8 & 3 & 1 & 18 & 15 & 2 & 14 & - & 6 & 1 & - & 1 & 103 \\
\hline Northeast & 5 & 8 & - & - & 4 & - & - & - & - & 5 & - & 2 & - & 24 \\
\hline North & 31 & 19 & 2 & - & 12 & 4 & I & 3 & - & 6 & - & 3 & 1 & 82 \\
\hline TOTAL & 94 & 44 & 13 & 2 & 53 & 39 & 3 & 20 & 1 & 20 & 4 & 7 & 3 & 303 \\
\hline
\end{tabular}

assigned to cluster IV; the two subgenotype F1 samples were related to cluster Ib. Correlating the RFLP patterns and the phylogenetic clusters of isolates belonging to genotype F for all Brazilian samples, we found that samples characterized as RFLP pattern FI were grouped in cluster II, whereas those classified as FII and FIII on the basis of RFLP patterns were related to isolates from cluster IV and Ib, respectively.

\section{Discussion}

The previously described co-circulation of HBV genotypes A, D and F in Brazil [31,33-39] was confirmed in the present study, which also found that no other HBV genotypes were present in a sample of 303 blood donors. The identification of genotype prevalence patterns in Brazil that are distinct from worldwide geographic distribution patterns could be a reflection of the intensely migratory and highly miscegenated character of the Brazilian population. Genotypes B and C, previously identified in a few Brazilian individuals, all of Asian origin [36,40], have not been detected in the present study. The absence of genotypes $\mathrm{B}$ and $\mathrm{C}$ may be explained by a combination of a limited sample size and an unbalanced distribution of individuals from Asian origin throughout the Brazilian territory (reflecting the tendency of Asian immigrants to concentrate in certain restricted geographic areas).

The distribution of HBV genotypes A and D in Brazil seemed to follow a gradient from northern to southern regions (Figure 1). North, Northeast and Southeast regions showed a higher prevalence of genotype $A$, the most common genotype in Brazil. The high rate of genotype $\mathrm{D}$ isolates in the South region could be related to the influx of immigrants from Central Europe (especially Germany and Italy) that occurred in that region at the beginning of the $20^{\text {th }}$ century. The balanced distribution of genotypes A and D in the Central-West region could be explained by the delayed occupation of that area by population migration flows from South, Southeast and Northeast regions.

HBV genotype A had been initially divided into two genetic subgroups, A1 and A2, on the basis of sequence divergence [6,7]. A previously described PCR-RFLP genotyping method has classified HBV isolates into more than 20 patterns [31]. Sequences showing patterns AI, AII and AVI clustered in subgroup A1, whereas those showing patterns AIII and AV were found exclusively in subgroup A2.

Table 2: S protein amino acid replacements and lamivudine-resistant $r t$ domain polymerase mutations found in blood donors.

\begin{tabular}{|c|c|c|c|c|}
\hline Sample & Genotype & Serotype & Determinant $a$ replacements & $\begin{array}{l}\text { Lamivudine resistance mutation } \\
\text { (P gene)* }\end{array}$ \\
\hline $358-S$ & $A$ & $a d w 2$ & YI00C & - \\
\hline $312-S E$ & A & adw2 & YIO0C & - \\
\hline 16I-CW & A & adw2 & YIOOC & - \\
\hline $043-N$ & A & $a d w 2$ & - & rtVI73L, rtLI80M, rtM204V \\
\hline $020-N$ & $\mathrm{D}$ & ayw3 & TII8V, AI28V & - \\
\hline $328-S$ & D & ayw3 & TII8V, Al28V & - \\
\hline $344-S$ & $\mathrm{D}$ & ayw3 & TII8V, AI28V & - \\
\hline 209-CW & $\mathrm{F}$ & adw4 & - & rtLI80M, rtM204I \\
\hline $052-N$ & $\mathrm{~F}$ & $a d w ?$ & LI27I & - \\
\hline
\end{tabular}

*Deduced amino acid sequence of HBV polymerase based on the shifted reading frame of the sequenced $\mathrm{S}$ gene (P gene: aa rt 9-236). 


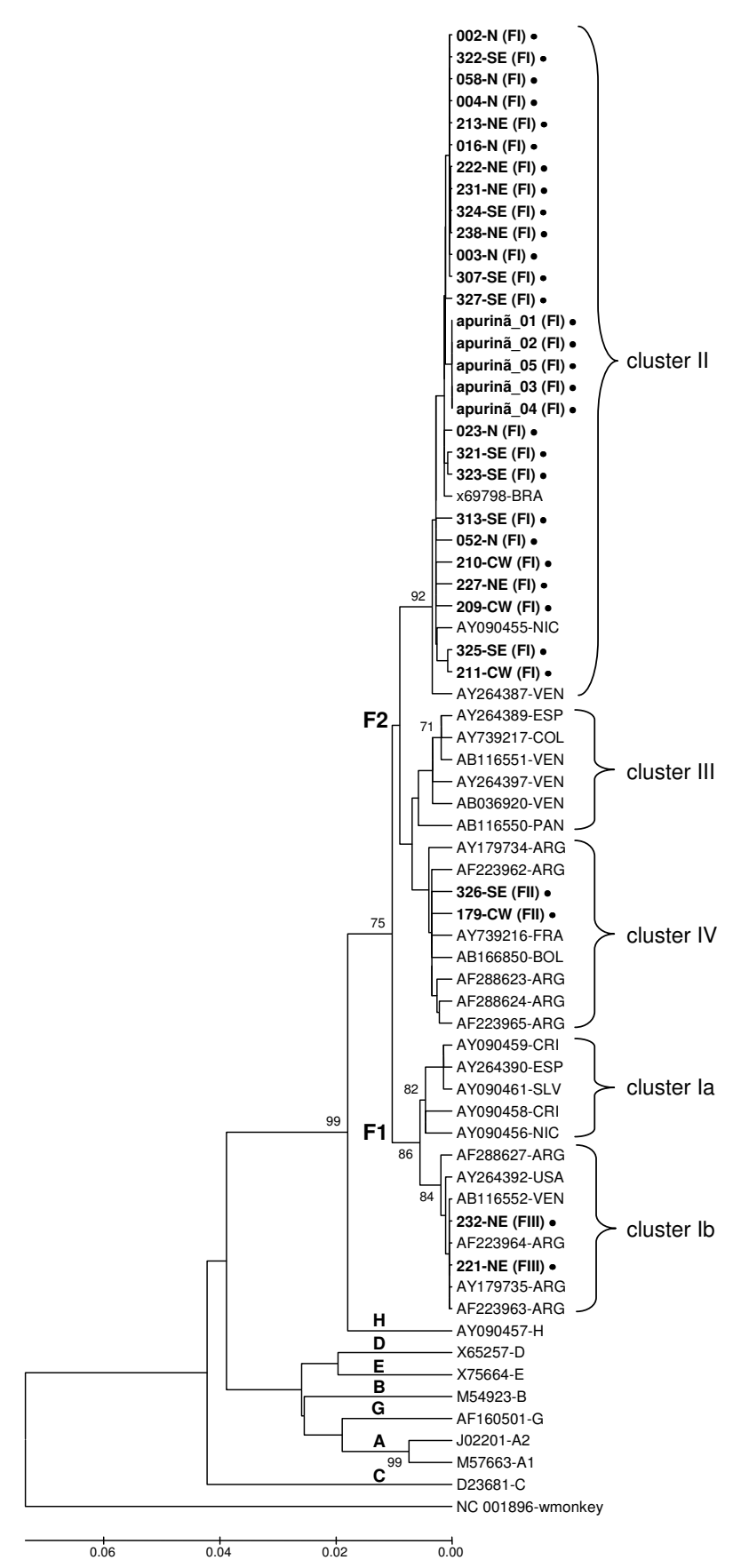

Figure 2

Phylogenetic-tree representing HBV genotype F isolates. Brazilian sequences determined in this study are represented in bold $(\bullet)$, designated by the corresponding region of the sample (N: North region; NE: Northeast region; CW: Central-West region; SE: Southeast region) with RFLP pattern in brackets. International sequences are designated with their accession number followed by their countries of origin.
In the present study, the RFLP and sequence analyses of genotype A isolates circulating in Brazil showed a high prevalence of isolates from subgroup A1 (90.2\%, Table 1), corroborating previous results and indicating that the HBV genotype A circulating in Latin America is not exclusively associated with the European influx, as once thought (reviewed in [4]). On the contrary, the massive African forced migration during the colonial times (from the $16^{\text {th }}$ to $19^{\text {th }}$ century) was a major contributor to the HBV circulation currently found in Brazil. The absence of genotype $\mathrm{E}$, which circulates in sub-Saharan Africa where substantial slave traffic occurred, could be explained by the relatively recent emergence of this genotype as a human pathogen, dating from the mid to late $19^{\text {th }}$ century [41] when the slave trade had already been abolished.

A large-scale study on the geographic distribution of HBsAg subtypes in Brazil, published in the late 1980s, reported a high incidence of $a d w 2$ (associated with genotype A) in all regions, except the South region, where subtypes ayw2 and ayw3 (both associated with genotype D) were the most prevalent [22]. These results are in accord with our current results. However, other findings of this previous study, including the reported absence of subtypes other than $a d w 2$ in Northeast region, a vast majority of the adw2 subtype in the Central-West region, and the high prevalence of subtype adw4 (genotype F) in the North region, are not corroborated by our study. These discrepancies may be explained by differences in methodology: Because the former study classified HBV isolates on the basis of differences in antigenic determinants [22], which usually requires high titers of HBsAg for subtype determination, it may have mischaracterized low titer samples that are readily classified using genotypic analyses. Alternatively, divergent conclusions could arise due to differences in sampling that affect the population under study and lead to a genotype prevalence bias with an underestimation of genotype F. For example, the current study analyzed serum samples from blood banks located in state capitals of Brazil, a sampling strategy that would tend to under-represent certain groups, such as Amerindians, that are not often voluntary blood donors. It is also possible that a given genotype induces more symptomatic infection, leading to a reduction in its prevalence in the potential blood donor population. Further studies comparing clinical outcomes in patients infected with genotypes $\mathrm{A}, \mathrm{D}$ and $\mathrm{F}$ will be required to address this question.

In general, HBV genotype $\mathrm{F}$, which is native to the Amerindians, showed a low prevalence in Brazil (13\%). This was true even in the North region where the native Amerindian population comprises a larger fraction of the total population. This result supports the findings of Moraes $e t$ al. [33] and contrasts with the high prevalence of genotype F described in other South American countries, including 
Venezuela $[19,20]$ and Argentina $[16,18]$. These data indicate that, in Brazil, the native Amerindian population has made a minor contribution to the population as a whole, a fact supported by an analysis of mitochondrial DNA $[42,43]$.

As a starting point for establishing a molecular characterization of Brazilian HBV genotype F isolates, we determined $S$ gene sequences. When combined with a phylogenetic analysis, nucleotide sequences of individual genes, in particular the $S$ gene, can reveal relationships that help to elucidate the molecular epidemiology of HBV $[4,25,44,45]$. The topology of the HBV genotype F phylogenetic tree showed that the great majority of Brazilian strains characterized in the present study could be classified as subgenotype F2, cluster II. Two previous studies have described one Brazilian sequence belonging to cluster II $[17,25]$. In the present study, HBV genotype F isolates with sequences closely related to those grouped in clusters IV and Ib were found, suggesting that Brazilian genotype F strains may not be derived from one another. Assuming that the five samples previously characterized as genotype F from the Apurinã tribe (apurina_01-05) represent the native original $\mathrm{HBV}$ of the Brazilian Indians, and further assuming that the great majority of Brazilian genotype F sequences determined in this study was closely related to them, it is reasonable to infer that HBV genotype $\mathrm{F}$ circulating in Brazil is mainly derived from the native aboriginal populations. However, the differences observed between the two sequences grouped in cluster Ib (232-NE; 221-NE) and the other genotype F sequences could indicate that two or three viral populations with distinct origin circulate in Brazil. Moreover, the existence of this well-defined cluster as the representative Brazilian isolate would indicate that HBV genotype $\mathrm{F}$ arose from a common ancestor, but evolved separately after becoming isolated in different regions of the Americas.

Genotyping using PCR-RFLP analysis and nucleotide sequencing gave the same result for all 62 samples tested, indicating that our PCR-RFLP genotyping method is appropriate for large-scale studies. Similar to our previous report on genotype A isolates [31], our results here demonstrate an interesting correlation between the RFLP patterns identified and the cluster analysis of HBV genotype F isolates. All FI RFLP-pattern isolates subjected to nucleotide sequencing were found to group into genotype $\mathrm{F}$ cluster II, whereas the two isolates grouped in cluster IV (326-SE; 179-CW) and the two isolates grouped in cluster Ib (232-NE; 221-NE) were classified as RFLP pattern FII and FIII, respectively. Although more extensive sampling will be necessary to confirm this relationship, it is possible that RFLP patterns could be used to establish to which cluster the HBV genotype F isolate is related.
The identification of a novel isoleucine substitution at residue 127 in one HBV genotype F isolate (052-N) classified by serotype using amino acid analysis reinforces the need for further investigation of genotype $\mathrm{F}$ strains. The deduced amino acid sequence of the $S$ gene product also revealed three isolates bearing the determinant $a$ substitution Y100C, which is associated with the HBsAg-negative/ anti-HBc-positive phenotype in blood donors from Venezuela [46] and has been found in an HBsAg-positive Brazilian patient [47]. Further studies will be required to determine whether this mutation is truly related to a reduction in HBsAg detection. The T118V-A128V double mutation was found in three genotype D/ayw3 (subgenotype D2) isolates. These substitutions, which have been found in other subgenotype D2 isolates [3], have recently been identified in Brazil (unpublished data), Spain, Sweden and Poland [48].

The deduced amino acid sequence of HBV polymerase showed that two isolates had substitutions in residues associated with lamivudine resistance. The frequent lamivudine-resistance rtL180M-rtM204V double mutation was detected in two isolates (043-N and 209-CW), while a third isolate $(043-\mathrm{N})$ displayed a rare rtV173L-rtL180MrtM204V triple mutation (Table 2). This triple mutant is known to exhibit reduced in vitro affinity for anti-HBs antibodies, similar to the hepatitis $\mathrm{B}$ vaccine escape mutant G145R [32,49]. These findings were unexpected given that the samples analyzed in the present study were derived from blood donors, a group of individuals not undergoing lamivudine therapy. However, lamivudineresistant isolates would eventually be expected to circulate in the environment as a result of contact with chronic hepatitis B patients undergoing lamivudine antiviral therapy, allowing healthy individuals, including blood donors, to become exposed to a primary infection with an HBV mutant strain. The presence of lamivudine-resistant isolates could also be related to previously reports of $\mathrm{HBV}$ isolates with a YMDD motif mutation in chronic hepatitis $B$ patients not treated with lamivudine $[50,51]$.

The evolutionary origins of $\mathrm{HBV}$ remain ill defined. Although some early studies have suggested a New World origin for this virus, the data are ambiguous and specific inferences should be drawn with caution [52,53]. The diversification of HBV genotypes is poorly understood, but estimates based on phylogenetic divergence rates have calculated that HBV genotypes diverged less than 6000 years ago (reviewed in [54]). The origin of genotype $F$ is particularly obscure, and may represent the first split from the human hepadnaviral ancestor (reviewed in [12]). As many authors have noted, a refined analysis of the evolutionary history of HBV will require more extensive sampling of HBV genomes. 


\section{Conclusion}

The distribution of HBV genotypes A and D identified in the present study followed an apparent gradient from northern to southern regions of Brazil, possibly reflecting the influence of early populations and settlement patterns during the process of occupying the country. The high prevalence of isolates from subgroup A1 (90.2\%) may denote a major contribution of forced African influx during the colonial slavery period to the current HBV genotype A circulation in Brazil.

In contrast to other Latin American countries, HBV genotype F showed a low prevalence in Brazil (13\%), even in the North region where the native aboriginal population has a greater influence. The topology of the phylogenetic tree for HBV genotype F strains allowed the classification of most strains into subgenotype F2 within cluster II. The existence of this well-defined cluster as the representative Brazilian isolate would indicate that HBV genotype F arose from a common ancestor, but evolved separately after becoming isolated in different regions of the Americas. The presence of some isolates of clusters IV and I (subgroup Ib) argues for the existence of two or more founder viral populations of genotype $\mathrm{F}$ in Brazil. Because the diversification of HBV genotypes remains poorly understood, particularly that of genotype $\mathrm{F}$, more extensive sampling of HBV genomes would be helpful in unraveling the complex evolutionary history of HBV.

\section{Methods}

\section{Serum samples}

A total of 303 serum samples from HBsAg-positive blood donors were collected between 2003 and 2004 at blood banks located in state capitals cities of Brazil representing different Brazilian regions. Thirty-eight samples were from the Santa Catarina State (South region); 56 samples were from Rio de Janeiro State (Southeastern region); 103 samples were from the three states that compose CentralWest region: Goiás (18), Mato Grosso (55), and Mato Grosso do Sul (30); 24 samples were from Pernambuco State (Northeast region); and 82 samples were from the North region (35 from Pará, 34 from Amazonas, and 13 from Amapá). In addition, five HBsAg-positive serum samples from the native Amerindian tribe Apurinã (Amazonas, Brazil), previously characterized as genotype $\mathrm{F}$ by PCR-RFLP, were included in the study.

\section{DNA extraction, amplification and RFLP analysis}

HBV DNA was phenol/chloroform extracted from $250 \mu \mathrm{L}$ of serum after treatment with $0.5 \mathrm{mg} / \mathrm{mL}$ of proteinase $\mathrm{K}$ for $4 \mathrm{~h}$ at $37^{\circ} \mathrm{C}$ in the presence of $0.2 \mathrm{M} \mathrm{NaCl}$ and $0.25 \%$ SDS, as previously described [55]. After precipitation with ethanol, the pellet was dried and resuspended in $30 \mu \mathrm{L}$ of distilled water. The pre-S/S genome region was amplified by semi-nested PCR. The first round contained one sense primer (C1, 5'-CTGTGGAGTTACTCTCGTTTTTGC-3', nt positions 1935-1958) and two antisense primers (S2, 5'GGGTTTAAATGTATACCCAAAGA-3', 819-841, and S22, 5'-GTATTTAAATGGATACCCACAGA-3', 819-841) located at the same position on the genome to facilitate the amplification of all HBV genotypes [33]. After an initial denaturation step ( $3 \mathrm{~min}$ at $94^{\circ} \mathrm{C}$ ), DNA was amplified using 35 cycles of $94^{\circ} \mathrm{C}$ for $40 \mathrm{~s}, 55^{\circ} \mathrm{C}$ for $1 \mathrm{~min}$, and $72^{\circ} \mathrm{C}$ for $2 \mathrm{~min} 30 \mathrm{~s}$, followed by a final elongation step $\left(7 \mathrm{~min}\right.$ at $\left.72^{\circ} \mathrm{C}\right)$. The first round of amplification was performed with $1 \mu \mathrm{L}$ of DNA and one unit of Taq DNA polymerase (Invitrogen, San Diego, CA) in a final volume of $25 \mu \mathrm{L}$. The second round of amplification was performed in a final volume of $50 \mu \mathrm{L}$, using $1 \mu \mathrm{L}$ of the first round PCR product, sense primer PS1 (5'-CCATATTCTTGGGAACAAGA-3', 2826-2845) and antisense primers S2 and S22, under the following conditions: 30 cycles of $95^{\circ} \mathrm{C}$ for $30 \mathrm{~s}, 52^{\circ} \mathrm{C}$ for $40 \mathrm{~s}$, and $72^{\circ} \mathrm{C}$ for $2 \mathrm{~min}$, followed by a final elongation step $\left(7 \mathrm{~min}\right.$ at $\left.72^{\circ} \mathrm{C}\right)$. Ten microliters of amplification product (about 1,200 bp in length) was loaded on 1\% agarose gels, electrophoresed, stained with ethidium bromide and visualized under UV light. Genotyping by RFLP analysis was performed as previously described [31] using $10 \mu \mathrm{L}$ of PCR products digested separately with two units of BamHI, EcoRI and StuI restriction endonucleases (Roche Molecular Biochemicals, Mannheim, Germany) at $37^{\circ} \mathrm{C}$ for 2 h. Digestion products were analyzed by electrophoresis in $2 \%$ agarose gel.

\section{Nucleotide sequencing and phylogenetic analysis}

The HBV S gene from 62 RFLP-genotyped samples was sequenced to verify the accuracy of our RFLP-based genotyping method. Twenty-two samples characterized as genotype A and 13 samples as genotype D by the RFLP-based method were randomly chosen for nucleotide sequencing. Twenty-seven samples determined as genotype $\mathrm{F}$ and 5 samples from native Amerindian tribe Apurinã (Amazonas, Brazil) previously characterized as genotype $F$ were also sequenced. The $\mathrm{S}$ gene was first amplified by PCR using a mixture of one sense primer (S1, 5'-CTTCTCGAGGACTGGGGACC-3', nt positions 124-143) and two antisense primers (S2, S22, described above) followed by purification of PCR products using QIAquick Gel Extraction Kit (QIAGEN, Valencia, CA). Purified PCR products were prepared for sequencing using a Big Dye Terminator 3.1 Cycle Sequencing Kit (Applied Biosystems, Foster City, CA) with external primers S1 and S2 or S22, internal sense primer S4 (5'-TGCTGCTATGCCTCATCTTCT-3', nt 416-436) and antisense S7 (5'-TGAGCCAGGAGAAACGGGCT-3', nt 676-656). The sequence was determined by separation and analysis of extension products using an automated ABI 3730 DNA Analyzer (Applied Biosystems, Foster City, CA). 
Raw HBV S gene sequence data were processed using programs from the Genetic Computer Group (GCG) package (University of Wisconsin, Madison, WI). Phylogenetic analysis was performed by comparing 681 bp sequences from the HBV $S$ gene determined in this study with HBV sequences available at GenBank. Sequences were aligned using the Clustal W program [56] and the phylogenetictree analysis was performed using the neighbor-joining method (bootstrap resampling test with 1,000 replicates) in MEGA version 3.0 software [57]. All sequences determined in this study have been deposited in the GenBank database [GenBank: EF690470 - EF690536].

\section{Authors' contributions}

FCAM carried out the molecular biology experiments and wrote the manuscript. FJDS, LCN, CAVN, HSMC, HCFF, JCPS, HAV, ARCMC, MMMM and RMBM were responsible for HBsAg evaluation and the epidemiological data of HBsAg positive blood donors. SAG conceived the study, participated in its design and coordination, and corrected the final version of the manuscript. All authors read and approved the final manuscript.

\section{Acknowledgements}

The authors express their gratitude to Dr. Christian Niel for his valuable comments and for manuscript revision, and to Plataforma Genômica Seqüenciamento de DNA/PDTIS-FIOCRUZ for performing the DNA sequencing.

\section{References}

I. Schaefer S: Hepatitis B virus: significance of genotypes. J Viral Hepat 2005, I2(2): III-124.

2. Norder H, Hammas B, Lee SD, Bile K, Courouce AM, Mushahwar IK, Magnius LO: Genetic relatedness of hepatitis B viral strains of diverse geographical origin and natural variations in the primary structure of the surface antigen. J Gen Virol 1993, 74 ( Pt 7): $134 \mid-1348$.

3. Norder H, Courouce AM, Coursaget P, Echevarria JM, Lee SD, Mushahwar IK, Robertson BH, Locarnini S, Magnius LO: Genetic diversity of hepatitis B virus strains derived worldwide: genotypes, subgenotypes, and HBsAg subtypes. Intervirology 2004, 47(6):289-309.

4. Campos RH, Mbayed VA, Pineiro YLFG: Molecular epidemiology of hepatitis B virus in Latin America. J Clin Virol 2005, 34 Suppl 2:S8-SI3.

5. Weber B: Diagnostic impact of the genetic variability of the hepatitis B virus surface antigen gene. J Med Virol 2006, 78 Suppl I:S59-65.

6. Bowyer SM, van Staden L, Kew MC, Sim JG: A unique segment of the hepatitis $B$ virus group $A$ genotype identified in isolates from South Africa. J Gen Virol 1997, 78 ( Pt 7): 1719-1729.

7. Kurbanov F, Tanaka Y, Fujiwara K, Sugauchi F, Mbanya D, Zekeng L, Ndembi N, Ngansop C, Kaptue L, Miura T, Ido E, Hayami M, Ichimura $H$, Mizokami M: A new subtype (subgenotype) Ac (A3) of hepatitis $B$ virus and recombination between genotypes $A$ and $E$ in Cameroon. J Gen Virol 2005, 86(Pt 7):2047-2056.

8. Sugauchi $F$, Orito E, Ichida $T$, Kato H, Sakugawa $H$, Kakumu $S$, Ishida T, Chutaputti A, Lai CL, Ueda R, Miyakawa Y, Mizokami M: Hepatitis $B$ virus of genotype B with or without recombination with genotype $\mathbf{C}$ over the precore region plus the core gene. J Virol 2002, 76(I 2):5985-5992.

9. Sugauchi F, Kumada $H$, Sakugawa $H$, Komatsu M, Niitsuma $H$, Watanabe H, Akahane Y, Tokita H, Kato T, Tanaka Y, Orito E, Ueda R, Miyakawa $Y$, Mizokami M: Two subtypes of genotype $\mathbf{B}(\mathbf{B a}$ and $\mathbf{B j})$ of hepatitis B virus in Japan. Clin Infect Dis 2004, 38(9): $1222-1228$.
10. Sakamoto T, Tanaka Y, Orito E, Co J, Clavio J, Sugauchi F, Ito K, Ozasa A, Quino A, Ueda R, Sollano J, Mizokami M: Novel subtypes (subgenotypes) of hepatitis $B$ virus genotypes $B$ and $C$ among chronic liver disease patients in the Philippines. J Gen Virol 2006, 87(Pt 7): 1873-1882.

II. Huy TT, Ushijima H, Quang VX, Win KM, Luengrojanakul P, Kikuchi K, Sata T, Abe K: Genotype C of hepatitis B virus can be classified into at least two subgroups. J Gen Virol 2004, 85(Pt 2):283-292.

12. Kramvis A, Kew M, Francois G: Hepatitis B virus genotypes. Vaccine 2005, 23(19):2409-2423.

13. Banerjee A, Kurbanov F, Datta S, Chandra PK, Tanaka Y, Mizokami M, Chakravarty R: Phylogenetic relatedness and genetic diversity of hepatitis B virus isolates in Eastern India. J Med Virol 2006, 78(9): | |64-| | 74.

14. Schaefer S: Hepatitis B virus taxonomy and hepatitis B virus genotypes. World J Gastroenterol 2007, I 3(I): I4-2I.

15. Miyakawa Y, Mizokami M: Classifying hepatitis B virus genotypes. Intervirology 2003, 46(6):329-338.

16. Telenta PF, Poggio GP, Lopez JL, Gonzalez J, Lemberg A, Campos RH: Increased prevalence of genotype $F$ hepatitis $B$ virus isolates in Buenos Aires, Argentina. J Clin Microbiol 1997, 35(7): $1873-1875$

17. Pineiro y Leone FG, Mbayed VA, Campos RH: Evolutionary history of Hepatitis B virus genotype $F$ : an in-depth analysis of Argentine isolates. Virus Genes 2003, 27(I): I03-II0.

18. Franca PH, Gonzalez JE, Munne MS, Brandao LH, Gouvea VS, Sablon $E$, Vanderborght $\mathrm{BO}$ : Strong association between genotype $F$ and hepatitis $B$ virus (HBV) e antigen-negative variants among HBV-infected argentinean blood donors. J Clin Microbiol 2004, 42(I I):5015-502I.

19. Blitz L, Pujol FH, Swenson PD, Porto L, Atencio R, Araujo M, Costa L, Monsalve DC, Torres JR, Fields HA, Lambert S, Van Geyt C, Nor$\operatorname{der} \mathrm{H}$, Magnius LO, Echevarria JM, Stuyver L: Antigenic diversity of hepatitis $B$ virus strains of genotype $F$ in Amerindians and other population groups from Venezuela. J Clin Microbiol I998, 36(3):648-65I.

20. Devesa M, Rodriguez C, Leon G, Liprandi F, Pujol FH: Clade analysis and surface antigen polymorphism of hepatitis $B$ virus American genotypes. J Med Virol 2004, 72(3):377-384.

21. Casey JL, Niro GA, Engle RE, Vega A, Gomez H, McCarthy M, Watts DM, Hyams KC, Gerin JL: Hepatitis B virus (HBV)/hepatitis D virus (HDV) coinfection in outbreaks of acute hepatitis in the Peruvian Amazon basin: the roles of HDV genotype III and HBV genotype F. J Infect Dis 1996, 174(5):920-926.

22. Gaspar AM, Yoshida CF: Geographic distribution of HBsAg subtypes in Brazil. Mem Inst Oswaldo Cruz 1987, 82(2):253-258.

23. Arauz-Ruiz P, Norder H, Visona KA, Magnius LO: Genotype F prevails in HBV infected patients of hispanic origin in Central America and may carry the precore stop mutant. J Med Virol 1997, 5 I (4):305-3 2

24. Norder H, Arauz-Ruiz P, Blitz L, Pujol FH, Echevarria JM, Magnius LO: The $T(1858)$ variant predisposing to the precore stop mutation correlates with one of two major genotype $F$ hepatitis $B$ virus clades. J Gen Virol 2003, 84(Pt 8):2083-2087.

25. Mbayed VA, Barbini L, Lopez JL, Campos RH: Phylogenetic analysis of the hepatitis B virus (HBV) genotype $F$ including Argentine isolates. Arch Virol 200।, I 46(9): $1803-1810$.

26. Souto FJD: Distribuição da hepatite B no Brasil: atualização do mapa epiemiológico e proposições para seu controle. Gastroenterol Endosc Dig 1999, I 8: | 43-150.

27. Viana S, Parana R, Moreira RC, Compri AP, Macedo V: High prevalence of hepatitis $B$ virus and hepatitis $D$ virus in the western Brazilian Amazon. Am J Trop Med Hyg 2005, 73(4):808-8I4.

28. Parana R, Almeida D: HBV epidemiology in Latin America. J Clin Virol 2005, 34 Suppl I:SI30-3.

29. Teles SA, Martins RM, Vanderborght B, Stuyver L, Gaspar AM, Yoshida CF: Hepatitis B virus: genotypes and subtypes in Brazilian hemodialysis patients. Artif Organs 1999, 23(1 2): 1074-1078.

30. De Castro L, Araujo NM, Sabino RR, Alvarenga F, Yoshida CF, Gomes SA: Nosocomial spread of hepatitis B virus in two hemodialysis units, investigated by restriction fragment length polymorphism analysis. Eur J Clin Microbiol Infect Dis 2000, 19(7):531-537. 
31. Araujo NM, Mello FC, Yoshida CF, Niel C, Gomes SA: High proportion of subgroup $A^{\prime}$ (genotype $A$ ) among Brazilian isolates of Hepatitis B virus. Arch Virol 2004, I 49(7): 1 383-1395.

32. Torresi J, Earnest-Silveira L, Deliyannis G, Edgtton K, Zhuang H, Locarnini SA, Fyfe J, Sozzi T, Jackson DC: Reduced antigenicity of the hepatitis $B$ virus $\mathrm{HBsAg}$ protein arising as a consequence of sequence changes in the overlapping polymerase gene that are selected by lamivudine therapy. Virology 2002, 293(2):305-3।3.

33. Moraes MT, Niel C, Gomes SA: A polymerase chain reactionbased assay to identify genotype $F$ of hepatitis B virus. Braz J Med Biol Res 1999, 32(I):45-49.

34. De Castro L, Niel C, Gomes SA: Low frequency of mutations in the core promoter and precore regions of hepatitis $B$ virus in anti-HBe positive Brazilian carriers. BMC Microbiol 200I, I:I0.

35. Teles SA, Martins RM, Gomes SA, Gaspar AM, Araujo NM, Souza KP Carneiro MA, Yoshida CF: Hepatitis B virus transmission in Brazilian hemodialysis units: serological and molecular followup. J Med Virol 2002, 68(I):4I-49.

36. Sitnik R, Pinho JR, Bertolini DA, Bernardini AP, Da Silva LC, Carrilho $\mathrm{FJ}$ : Hepatitis $B$ virus genotypes and precore and core mutants in Brazilian patients. / Clin Microbiol 2004, 42(6):2455-2460.

37. Carrilho FJ, Moraes CR, Pinho JR, Mello IM, Bertolini DA, Lemos MF, Moreira RC, Bassit LC, Cardoso RA, Ribeiro-dos-Santos G, Da Silva LC: Hepatitis B virus infection in Haemodialysis Centres from Santa Catarina State, Southern Brazil. Predictive risk factors for infection and molecular epidemiology. BMC Public Health 2004, 4: 13.

38. Rezende RE, Fonseca BA, Ramalho LN, Zucoloto S, Pinho JR, Bertolini $\mathrm{DA}$, Martinelli AL: The precore mutation is associated with severity of liver damage in Brazilian patients with chronic hepatitis B. J Clin Virol 2005, 32(I):53-59.

39. Ferreira RC, Teles SA, Dias MA, Tavares VR, Silva SA, Gomes SA Yoshida CF, Martins RM: Hepatitis B virus infection profile in hemodialysis patients in Central Brazil: prevalence, risk factors, and genotypes. Mem Inst Oswaldo Cruz 2006, I $01(6): 689-692$

40. Ribeiro NR, Campos GS, Angelo AL, Braga EL, Santana N, Gomes MM, Pinho JR, De Carvalho WA, Lyra LG, Lyra AC: Distribution of hepatitis $B$ virus genotypes among patients with chronic infection. Liver Int 2006, 26(6):636-642.

4I. Mulders MN, Venard V, Njayou M, Edorh AP, Bola Oyefolu AO, Kehinde MO, Muyembe Tamfum JJ, Nebie YK, Maiga I, Ammerlaan W, Fack F, Omilabu SA, Le Faou A, Muller CP: Low genetic diversity despite hyperendemicity of hepatitis $B$ virus genotype $E$ throughout West Africa. J Infect Dis 2004, I 90(2):400-408.

42. Carvalho-Silva DR, Santos FR, Rocha J, Pena SD: The phylogeography of Brazilian Y-chromosome lineages. Am J Hum Genet 200I, 68(I):28I-286.

43. Devesa M, Pujol FH: Hepatitis B virus genetic diversity in Latin America. Virus Res 2007.

44. Norder H, Hammas B, Lofdahl S, Courouce AM, Magnius LO: Comparison of the amino acid sequences of nine different serotypes of hepatitis $B$ surface antigen and genomic classification of the corresponding hepatitis B virus strains. Gen Virol 1992, 73 ( Pt 5): 120|-1208.

45. Bartholomeusz A, Schaefer S: Hepatitis B virus genotypes: comparison of genotyping methods. Rev Med Virol 2004, I 4(I):3-16.

46. Gutierrez C, Devesa M, Loureiro CL, Leon G, Liprandi F, Pujol FH: Molecular and serological evaluation of surface antigen negative hepatitis $B$ virus infection in blood donors from Venezuela. J Med Virol 2004, 73(2):200-207.

47. Santos EA, Sucupira MV, Arabe J, Gomes SA: Hepatitis B virus variants in an HIV-HBV co-infected patient at different periods of antiretroviral treatment with and without lamivudine. BMC Infect Dis 2004, 4:29.

48. Arauz-Ruiz P, Norder H, Robertson BH, Magnius LO: Genotype H: a new Amerindian genotype of hepatitis $B$ virus revealed in Central America. J Gen Virol 2002, 83(Pt 8):2059-2073.

49. Cooley L, Ayres A, Bartholomeusz A, Lewin S, Crowe S, Mijch A, Locarnini S, Sasadeusz J: Prevalence and characterization of lamivudine-resistant hepatitis B virus mutations in HIV-HBV co-infected individuals. Aids 2003, 17 (I I): 1649-1657.

50. Matsuda M, Suzuki F, Suzuki Y, Tsubota A, Akuta N, Hosaka T, Someya T, Kobayashi M, Saitoh S, Arase Y, Satoh J, Takagi K, Koba- yashi M, Ikeda K, Kumada H: Low rate of YMDD motif mutations in polymerase gene of hepatitis $B$ virus in chronically infected patients not treated with lamivudine. J Gastroenterol 2004, 39(I):34-40.

5I. Huang ZM, Huang QW, Qin YQ, He YZ, Qin HJ, Zhou YN, Xu X, Huang MJ: YMDD mutations in patients with chronic hepatitis B untreated with antiviral medicines. World J Gastroenterol 2005, II (6):867-870

52. Bollyky PL, Holmes EC: Reconstructing the complex evolutionary history of hepatitis B virus. J Mol Evol I999, 49(I): |30-I4I.

53. Fares MA, Holmes EC: A revised evolutionary history of hepatitis B virus (HBV). J Mol Evol 2002, 54(6):807-8I4.

54. Gunther S: Genetic variation in HBV infection: genotypes and mutants. J Clin Virol 2006, 36 Suppl I:S3-SI I.

55. Niel C, Moraes MT, Gaspar AM, Yoshida CF, Gomes SA: Genetic diversity of hepatitis $B$ virus strains isolated in Rio de Janeiro, Brazil. J Med Virol 1994, 44(2): 180-186.

56. Thompson JD, Higgins DG, Gibson TJ: CLUSTAL W: improving the sensitivity of progressive multiple sequence alignment through sequence weighting, position-specific gap penalties and weight matrix choice. Nucleic Acids Res 1994 22(22):4673-4680.

57. Kumar S, Tamura K, Nei M: MEGA: Molecular Evolutionary Genetics Analysis software for microcomputers. Comput Appl Biosci 1994, I0(2): |89-19|.

Publish with BioMed Central and every scientist can read your work free of charge

"BioMed Central will be the most significant development for disseminating the results of biomedical research in our lifetime. "

Sir Paul Nurse, Cancer Research UK

Your research papers will be:

- available free of charge to the entire biomedical community

- peer reviewed and published immediately upon acceptance

- cited in PubMed and archived on PubMed Central

- yours - you keep the copyright
BioMedcentral 